\title{
PROCEEDINGS OF THE ELEVENTH ANNUAL MEETING OF THE PALEONTOLOGICAL SOCIETY, HELD AT BOSTON, MASSACHUSETTS, DECEMBER 30-31, 1919.
}

\author{
R. S. BASSLER, Secretary
}

\section{CONTENTS}

Page

Report of the Council.................................. 199

Secretary's report ................................ 199

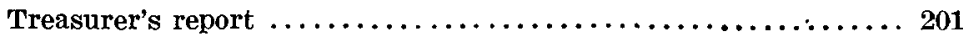

Appointment of Auditing Committee...................... 201

Election of officers and members......................... 202

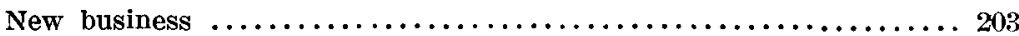

Necrology ....................................... 203

Presentation of papers on paleontology ................... 204

Supposed fossil horse from the late Pleistocene found at Monroe, Orange County, New York [abstract]; by John M. Clarke and W. D. Matthew ............................... 204

Recent restorations of fossil invertebrates; by John M. Clarke.. 204 The "good use" of the term "fossil"; by Richard M. Field...... 204

Paleontological collections in the vicinity of Boston [abstract]; by Percy E. Raymond.......................... 205

Value of foraminifera in stratigraphic correlation [abstract]; by Joseph A. Cushman.......................... 205

Stratigraphic significance of Orthaulax [abstract] ; by C. Wythe Cooke.................................... 206

Presence of Upper Silurian sandstone in Essex County, northeastern Massachusetts [abstract] ; by A. F. Foerste......... 206

Intercalation of thecal plates in Holocystites in connection with the criteria upon which species can be distinguished [abstract] ; by A. F. Foerste.............................. 207

Revision of the Anticosti section [abstract] ; by W. H. Twenhofel 209 Report of the Auditing Committee.................... 209 Studies in variation and a proposed classification of variants: Presidential address by Robert T. Jackson................... 209 Hydrozoan affinities of Serpulites Sowerby [abstract]; by W.

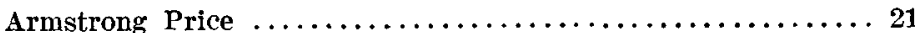


I'age

Paleozoic section of the lower Mackenzie River ; by E. M. Kindle. 211

Echinoderms of the Iowa Deronian [abstract]; by A. O. Thomas. 211

Session of Wednesday, December $31 \ldots \ldots \ldots \ldots \ldots \ldots \ldots \ldots \ldots \ldots \ldots \ldots$

Symposium on teaching of paleontology $\ldots \ldots \ldots \ldots \ldots \ldots \ldots \ldots \ldots \ldots$

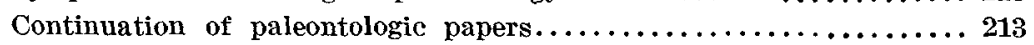

Bibliographic studies of the Cambrian [abstract]; by Charles E.

Resser ............................... 213

Correlation of the Middle Cambrian of Newfoundland and Great

Britain [abstract]; by B. F. Howell................ 214

Cambrian formations and faunas of the upper Mississippi Valley;

by E. O. Ulrich......................... 214

Trilobites as ancestors [abstract]; by Percy E. Raymond....... 214

Origin of the "beach rock" (Coquina) at Loggerhead Key, Tortu-

gas [abstract] ; by Richard M. Field............... 215

Foraminiferal fauna of the Byram marl [abstract]; by Joseph A.

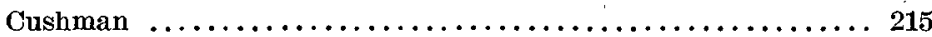

Stratigraphy of the Virgin Islands of the United States and of Culebra and Vieques Islands [abstract]; by Thomas Wayland Vaughan .............................. 216

Geologic reconnaissance in Santo Domingo [abstract]; by $\mathrm{C}$.

Wythe Cooke............................. 217

Notes on the teaching of paleobotany ; by Marion D. Weston.... 220

Method of appearance of additional arms on increasing age in

Caryocrinites [abstract] ; by A. F. Foerste............. 220

Status and limits of the Paleocene [abstract]; by W. D. Matthew 221

Study of the life processes in fossils; by R. S. Bassler........ 222

Sponges of the Middle Cambrian; by Charles D. Walcott...... 222

Inorganic evidences of disconformities in limestone; by Richard

M. Field................................ 222

Minutes of sectional meeting on vertebrate paleontology $\ldots \ldots \ldots \ldots \ldots 22$

Further discussion of the ecological composition of the Eagle

Creek flora [abstract] ; by Ralph W. Chaney............. 222

New mounts in the Princeton Geological Museum [abstract]; by

William J. Sinclair....................... 223

Study of the entelodonts [abstract] ; by Edward L. Troxell..... 223

Mounted skeleton of Moschops capensis Broom [abstract]; by William K. Gregory....................... 223

Small mammals in the Marsh Collection at Yale University [abstract]; by Edward I. Troxell.................. 223

Tertiary artiodactyls from the Marsh Collection [abstract]; by

Richard S. Lull............................ 224

Oligocene Equidæe in the Marsh Collection [abstract] ; by John P.

Buwalda ................................ 224

Pawnee Creek beds of Colorado [abstract] ; by F. B. Loomis..... 224

New specimen of the Pleistocene bear, Arctotherium from Texas

[abstract] ; by W. D. Matthew................... 224

Northrotherium shastense, a Pleistocene ground sloth of North America, with remarks on the Megalonychidæ; by Chester Stock 225 
Page

Register of the Boston meeting, 1919.................... 225

Officers, correspondents, and members of the Paleontological Society .... 226 Minutes of the Ninth Annual Meeting of the Pacific Coast Section of the

Paleontological Society; by Chester Stock, Secretary.......... 231

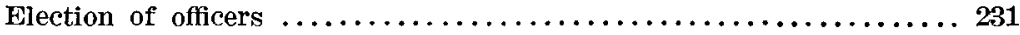

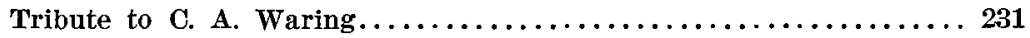

Reading of paleontological papers...........................

Stratigraphic and faunal relations of the Meganos group (Middle

Eocene), California; by B. I. Clark............... 232

Cenozoic history of the ground sloth group [abstract]; by Chester

Stock ................................ 232

Juncheon and excursion........................ 232

\section{Sesston of Tuesday, December 30}

The eleventh annual meeting of the Society was called to order by President Jackson at 10 a. m., December 30, in the Rogers Building of the Massachusetts Institute of Technology. After welcoming the Society to Boston, President Jackson called upon the Secretary to present the report of the Council.

\section{REPORT OF COUNCIL}

To the Paleontological Society, in eleventh annual meeting assembled:

The formal meetings of the Council during the past year have been limited to one at Baltimore, following the tenth annual meeting, and one held just before the present session. Matters of business not discussed at these meetings have been transacted by correspondence, as heretofore. A résume of the Council's administration for the eleventh year of the Society is presented in the following reports of the Secretary and Treasurer :

SECRETARY's RePORT

To the Council of the Paleontological Society:

The Secretary's annual report for the year ending December 27, 1919. is as follows:

The proceedings of the tenth annual meeting of the Society, held at Baltimore, Maryland, December 28, 1918, are printed in volume 30, pages 143-164, of the Bulletin of the Geological Society of America.

The preliminary ballot for officers and the announcement that the eleventh annual meeting of the Society would be held at Boston, as a guest of the Geological Society of Boston, was issued March 19, 1919. 
The Council roted that the dues of the members in the military service of the United States abroad should be remitted during this period. The Council also voted approval of the issuance of a war record card to the members, so that their activities may be preserved in the records of the Society.

The nomination of Dr. T. Wayland Vaughan as representative of the Society in the National Research Council for the year ending May 1, 1920, was approved by the Council. At the Council meeting just concluded, the nomination of Dr. Vaughan to the same position for the three-year period ending May 1, 1923, was recommended.

Membership.-During the year the Society has lost four of its members by death: Mr. C. A. Waring, of the State Mining Bureau of California, well known in the field of invertebrate paleontology of the Pacific coast; Mr. Lawrence M. Lambe, vertebrate paleontologist of the Canadian Geological Survey; Dr. Joseph Barrell, eminent geologist and teacher, of Yale University, and Mr. Victor Lyon, city engineer of Jeffersonville, Indiana, and long an energetic collector and student of fossils in the celebrated Falls of the Ohio area.

One member has resigned during the year and ten new members are under consideration for election. At the election just concluded two of our members became Fellows of the Geological Society of America. The result of these various changes leaves the total number of members at the end of 1919 as 194.

Pacific Coast Section.-The ninth annual meeting of the Pacific Coast Section of the Paleontological Society was held at Pasadena, California, June 20, 1919, in conjunction with the Cordilleran Section of the Geological Society of America and the Seismological Society of America, with Prof. G. D. Lauderback as presiding officer. During the presentation of the papers on geology and paleontology Prof. B. L. Clark presided.

The following officers for the section were elected for the ensuing year:

President, John C. Merriam.

Vice-President, EARL L. PACKaRd.

Secretary, Chester Stock.

Several papers on paleontology were presented, and following the program the members made an excursion to the asphalt deposits at Rancho La Brea, and later the Museum at Los Angeles was visited.

The minutes of this section are printed on pages 231 to 232 of this Bulletin.

$$
\text { Respectfully submitted, }
$$

Washington, D. C., December 30, 1919.
R. S. Bassler,

- Secretary. 
Treasurer's RePORT

To the Councit of the Paleontological Society:

The Treasurer begs to submit the following report of the finances of the Society for the fiscal year ending December 26, 1919:

RECEIPTS

Cash on hand December 13, 1918 $\$ 622.38$

Membership fees $(1917) \ldots \ldots \ldots \ldots \ldots \ldots \ldots \ldots \ldots \ldots \ldots \ldots 6 . \ldots \ldots$

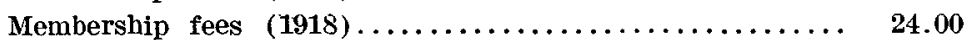

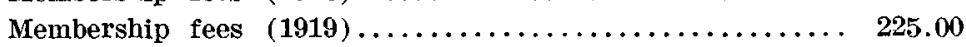

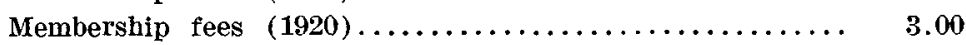

Interest, Connecticut Savings Bank.............. 19.74

EXPEN DITURES

Treasurer's office :

Treasurer's allowance $\ldots \ldots \ldots \ldots \ldots \ldots \ldots \ldots \ldots 25.00$

Postage $\ldots \ldots \ldots \ldots \ldots \ldots \ldots \ldots \ldots \ldots \ldots \ldots \ldots$

Secretary's office: $\quad \$ 32.00$

Secretary's allowance $\ldots \ldots \ldots \ldots \ldots \ldots \ldots \ldots \ldots \$ \ldots 50.00$

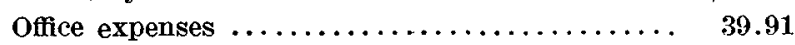

Clerical help $\ldots \ldots \ldots \ldots \ldots \ldots \ldots \ldots \ldots \ldots \ldots .25 .00$

Geological Society of America:
For printing programs, etcetera.......... $\$ 17.80$

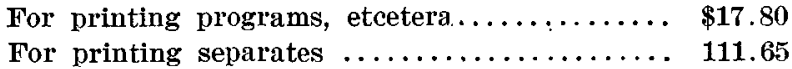

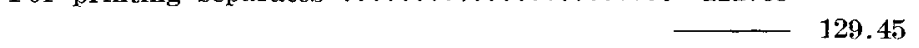

276.30

Balance on hand December 26, 1919

$\$ 623.76$

Net increase in funds. $\ldots \ldots \ldots \ldots \ldots \ldots \ldots \ldots \ldots \ldots \ldots \ldots \ldots \ldots, \$ 1.38$

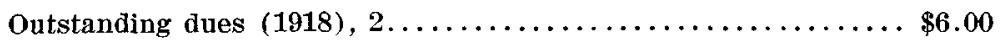

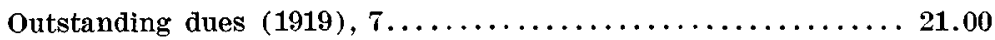

Respectfully submitted,

R. S. LULL, 27.00

New Haven, Connecticut, December 26, 1919.

Treasurer.

\section{APPOINTMENT OF AUDITING COMMITTEE}

The appointment of a committee to audit the Treasurer's accounts was in order following the reading of his report. The chairman selected P. E. Raymond and R. M. Field for this purpose. 


\section{ELECTION OF OFFICERS AND MEMBERS}

The results of the ballots for the election of officers for 1920 and of new members were then announced, as follows:

OFFICERS FOR 1920

President:

F. B. Loomis, Amherst, Mass.

First Vice-President:

E. C. Case, Ann Arbor, Mich.

Second Vice-President:

Ralph Arnold, Los Angeles, Calif.

Third Vice-President:

E. M. Kindle, Ottawa, Canada

Secretary:

R. S. BAssLeR, Washington, D. C.

Treasurer:

Richard S. Luld, New Haven, Conn.

Editor:

W. D. Matrhews, New York City

NEW MEMBERS

Charles L. Camp, American Museum of Natural History, New York City.

Thomas Henry Glark, South Weymouth, Mass.

Horace N. Coryels, Department of Geology, Columbia University, New Yoris City.

Georges Crozer, 17 Chemin des Celestins, Oullins (Rhone), France.

Bela Hubbard, Queens College, Kingston, Ontario.

George S. Hume, Geological Survey of Canada, Ottawa, Canada.

Malcolm R. Thorpe, Peabody Museum, New Haven, Conn.

Katherine R. H. Van Winkle, 126 Kelvin Place, Ithaca, N. Y.

The President then brought up the following two nominations for membership which had received the approval of the Council, but which had arrived too late for the printed ballot: 
Radph W. Chanex, Old Science Hall, Iowa City, Iowa. Engaged in study of paleobotany. Proposed by F. H. Knowlton and R. S. Bassler.

CHartes E. Decker, University of Oklahoma, Norman, Oklahoma. Engaged in study of stratigraphy and invertebrate paleontology. Proposed by Charles Schuchert and R. S. Bassler.

On motion and by unanimous vote, the Secretary was instructed to cast the ballot of the Society for the election of Messrs. Chaney and Decker.

\section{NEW BUSINESS}

The recommendation of the Council that Dr. T. Wayland Vaughan be. nominated to succeed himself as the representative of the Society on the National Research Council for the three-year term ending May 1, 1923, was on motion and vote, now duly approved by the members.

The Secretary then presented briefly the results of the war record cards. issued earlier in the year, which showed that an unusually large percentage of the members had been either in active military service or had: been teaching in the several training corps.

President Jackson now called for the report of the Williston Memorial' Committee. This was presented by W. K. Gregory, who outlined the scope of a proposed memorial volume in honor of Professor Williston and discussed plans for financing the project.

The next matter of business was a motion by P. E. Raymond to the effect that a committee be appointed to prepare a list of not more than 1,000 North American index fossils for use in teaching paleontology.

On vote, this was carried, and President Jackson appointed J. C. Merriam, Charles Schuchert, Gilbert Van Ingen, E. W. Berry, and P. E. Raymond as the committee for this purpose.

\section{NECROLOGY}

Memorial addresses in tribute to the lives of the four members of the Society who passed away during the year were then presented, as follows:

Chester Stock gave an account of the life of Mr. C. A. Waring and enumerated his researches in the field of the invertebrate paleontology of the Pacific Coast.

R. S. Lull touched on the many activities of Prof. Joseph Barrell, but brought out particularly his researches on paleontologic subjects.

R. S. Bassler spoke of his pleasant personal experiences with $\mathrm{Mr}$. Victor W. Lyon, of Mr. Lyon's researches upon fossil echinoderms, and: of his early geological work with his father, Mr. Sidney S. Liyon. 


\section{PRESENTATION OF PAPERS ON PALEONTOLOGY}

At 11 a. m., with the conclusion of the business meeting, the reading of papers was commenced by the presentation of a short discussion by each of the authors of an interesting occurrence of a fossil horse in New York State. The specimens on which this discovery was based were exhibited and the subject was discussed by F. B. Loomis and the authors.

SUPPOSED FOSSIL HORSE FROM THE LATE PLEISTOCENE FOUND AT MONROE, ORANGE COUNTY, NEW YORK

BY JOHN M. CLARKE AND W. D. MATTHEW

(Abstract)

In the State Museum at Albany is part of the skeleton of the mastodon from a postglacial peat-bog in Monroe County, New York. This find was investigated by Dr. Clarke, and with the mastodon bones were found a lower jaw, femur, etcetera, of a horse and part of the femur of a bear. The horse shows no characters to distinguish it from the domestic species, but the state of preservation of the bones indicates, although not positively, that it is not of recent introduction and is coeval with the mastodon. The bear femur appears to be too large for the black bear, Ursus americanus, and accords in size with the grizzly, $U$. horribilis, but it is not further determinable.

If these fossils are of the same age as the mastodon, they indicate (1) that native species of Equus survived the Wisconsin glaciation in eastern North America; (2) that a larger species of bear, perhaps the grizzly, existed at the same time and place.

Several very interesting restorations of Devonian marine life now on exhibition at the New York State Museum were then described by Dr. Clarke and illustrated with colored lantern slides.

\section{RECENT RESTORATIONS OF FOSSIL INVERTEBRATES}

BY JOHN M. CLARKE

Our use of the term"fossils" was discussed in the next"paper and suggestions for its proper usage were offered. The paper was discussed by President Jackson and Dr. John M. Clarke.

THE "GOOD USE" OF THE TERM "FOSSIL"

BY RICHARD M. FIELD

For the benefit of the visiting paleontologists, Dr. Raymond described the local collections of fossils and announced arrangements for personally conducted tours through the various museums of Boston and vicinity. 
PALEONTOLOGICAL COLLECTIONS IN THE VICINITY OF BOSTON

BY PERCY E. RAYMOND

(Abstract)

The Boston Society of Natural History has a small but interesting series of the fossils of New England, among which is one of unusual importance, the type of Paradoxides harlani.

There is no public exhibition of fossils at the Massachusetts Institute of Technology, but a number of collections may be consulted there, particularly the Pleistocene shells from about Boston.

At the Museum of Comparative Zoology at Harvard there are very large collections of invertebrate fossils and excellent series of some groups of vertebrates, especially fishes. Noteworthy among the invertebrates are the following: Schary and Barrande collections from the Paleozoic of Bohemia; Schultze collection from the Devonian of the Eifel; Haeberlein collection from Solenhofen; Dyer, Day, Taylor, and Walcott collections from the Ordovician and Silurian of America; Wachsmuth collection of crinoids and a very large collection of European cephalopods and other mollusca. Among the vertebrates are mounted specimens of moas and edentates, some unique birds from the Tertiary, amphibians and reptiles from the late Paleozoic of Texas and Scotland, etcetera.

The increasing use and the value of such microscopic organisms as the foraminifera in stratigraphic work was then described. The paper was discussed by Dr. John M. Clarke, with replies by the author.

\section{VALUE OF FORAMINIFERA IN STRATIGRAPHIC CORRELATION}

BY JOSEPH A. CUSHMAN

\section{(Abstract)}

The foraminifera have not been greatly used in correlation work in America; workers have been lacking and collections few. In recent years, however, the United States Geological Survey has accumulated many collections from the Coastal Plain region, Panama, and the West Indies which are rich in fossil foraminifera.

A study of some of these has already proved that the foraminifera are excellent for use in stratigraphic correlations, and further study will probably result in numerous detailed faunas which can easily be distinguished from one another.

The author of the next paper presented a discussion of the importance and significance of the various species of the gastropod genus Orthaulax, illustrating his remarks by lantern slides. 


\section{STRATIGRAPHIC SIQNIFICANCE OF ORTHAULAX}

BY C. WYTEE COOKE

\section{(Abstract)}

Three species of Orthaulax have been described. The genotype, o. inornatus Gabb, which has been supposed to be restricted to the Oligocene, was recently rediscovered in beds of basal Miocene age (Baitoa formation) in Santo Domingo at what may be the type locality. It is known also from the Tampa "silex beds" (Oligocene). The stratigraphic range of 0 . gabbi Dall appears to be very nearly the same as that of $O$. inornatus, but the two species have never been found in the same beds. O. gabbi comes from the Chipola marl of Florida and from the Culebra formation of Panama. Orthaulas pugnax (Heilprin) is found in the Tampa "silex beds," the lower part of the Chattahoochee formation near Bainbridge, Georgia; the Antigua formation, and in the Culebra formation of Panama. Its known range is Middle and Upper Oligocene.

The species of Orthaulas at Aguadilla, Porto Rico, referred to by Dr. Maury under the nude name of aguadillensis, is abundant in beds supposed to be of Miocene age, at Palo Copado, Azua Province, Dominican Republic, and it occurs also on the Island of Saint Croix. Its range is probably Miocene and Oligocene.

A Silurian horizon, apparently new to the Boston Basin, was indicated in the next paper, which was illustrated by the original specimens forming the basis of the determination.

\section{PRESENCE OF UPPER SILURIAN SANDSTONE IN ESSEX COUNTY, NORTHEASTERN MASSACHUSETTS}

\section{BY A. F. FOERSTE}

\section{(Abstract)}

In 1893 John H. Sears, curator of geology at the Peabody Academy of Science, in Salem, Massachusetts, published his Geological Map of Essex County, Massachusetts, in the Bulletin of Essex Institute. On the legend accompanying this map the areas colored yellow and numbered 18 are stated to consist of lime slate, quartzite, and sandstone, thus indicating the presence of clastic rocks. In the hope of finding fossils, the present writer, during the summer of 1894, visited the area southwest of Rowley and also that extending from Middleton northeastward toward Topsfield. Somewhere in the latter area specimens of Leperditia were found in a relatively soft quartzite or sandstone, but the writer was unable to identify the species or to refer them to a definite horizon. In 1918 the best specimens were submitted to Dr. R. S. Bassler, of the United States National Museum, and identified by him as belonging to the Leperditia alta group, thus suggesting the presence of strata of Cayugan or upper Silurian age. 
As far as may be determined from memory, the specimens of Leperditia were found in a quartzitic rock forming an exposure about 10 square yards in area along the upper part of a hilly area, somewhere north of Howe station. From Howe station the main road to Topsfield starts off northward. About a mile from Howe station another road branches off southeastward for half a mile, and then curves northward across Nichol Brook. On the writer's copy of Sears's map the statement north $20^{\circ}$ west occurs on the northwest side of the crossing of this branch road over Nichol Brook, and somewhēre in this neighborhood the Leperditia are believed to have been found.

Evidently it is highly desirable that the Leperditia locality should be redis. covered. An attempt made during the Christmas holiday week of 1919 failed dismally, not even the quartzite being found. Under these circumstances, the writer no longer being situated favorably for further search, it has been deemed best to leave to others the task of rediscovering the Leperditia locality, and the only specimen left from the original collection made by the writer has been deposited with Prof. Percy E. Raymond, of Harvard University.

The Leperditia locality lies about 17 miles east of north from Boston. The desirability of rediscovering this locality has been increased by the discovery bs Mr. Arthur Keith, in 1915, of numerous specimens of Camarotcechia and of a few other fossils about 10 miles northeast of the Leperditia locality, immediately south of Glen Mills, at the corner where the road to Rowley branches off eastward. Here the fossils occur at the base of a volcanic mud flow. Their age is regarded tentatively as low in the Devonian.

The great variation in plate structure in the cystid genus Holocystites and related genera was recalled to the members by the author of the next paper and the reason for their variation was explained. Doctors O'Connell and Jackson, Ulrich, and Foerste took part in the discussion following the paper.

INTERCALATION OF THECAL PLATES IN HOLOCYSTITES IN CONNECTION WITH THE CRITERIA UPON WHICH SPECIES CAN BE DISTINGUISHED

BY A. F. FOERSTE

(Abstract)

The genus Holocystites was founded by Hall on his species Holocystites cylindricus. This species is described by Hall as consisting of at least six encircling rows of hexagonal plates, each row containing eight plates, the plates of successive rows alternating with each other. In addition to these six encircling rows, there is at least one additional row at the base, and at the top of the theca there is a series of circum-oral plates. The number of species in the Racine of Wisconsin and northern Illinois, which are strictly congeneric with Holocystites cylindricus, includes at least Holocystites abnormis and Holocystites alternatus.

Holocystites alternatus is of special interest, since it departs from the pri- 
mary simplicity of structure of the genotype in the presence of more or less numerous intercalated plates, resulting in a considerable variety of patterns in the mature specimens. Young specimens of this species, however, probably were quite typical in appearance. This is suggested by the fact that if the margins of all plates are reduced at the same rate, the smaller plates will disappear first, and then those next in size, until only the primary plates remain. These primary plates in that case, moreover, will then be arranged in transverse rows, eight in a row, in such a manner that if the plates were brought closer together those in successive rows would alternate with each other, and their interference on growth would tend to produce hexagonal outlines, as in Holocystites cylindricus.

Between the first and second transverse rows beneath the circum-oral plates, intercalation frequently is confined to single plates, inserted at the angles of the primary plates, resulting in pentagonal outlines in the intercalated plates. Additional intercalation at the apex of the latter results in the truncation of the latter, producing an hexagonal outline, the second intercalated plate being triangular. Similar simplicity of structure may occur between the second and third transverse rows of plates, and even between the third and fourth rows, counting downward from the top.

Beneath the third transverse row, in some specimens, intercalation may take place at three successive intervals, resulting in a more or less complicated pattern of small plates. Much less frequently complicated patterns of small plates occur also between the second and third transverse rows of plates and even between the first and second rows.

The primary plates of each transverse row usually remain in contact with each other laterally or are separated by two intercalated plates, one of which has wedged in from above and the other from below. In other words, additional plates appear in much greater numbers between the transverse rows of primary plates than between the adjacent primary plates of the same row. The growth of the animal within the theca appears to have produced tension chiefly in the axial direction, resulting, in Holoycstites alternatus, in frequent intercalation of plates, especially toward the base in some specimens. This resulted in a theca which was conspicuously elongated, especially toward the base.

In typical Holocystites abnormis a similar elongation of the theca was produced by the elongation of the individual primary plates without the addition of intercalated plates.

If Holocystites scutellatus, Holocystites ovatus, and Holocystites winchelli are to be regarded as genuine species of Holocystites, it is evident that considerable variation in the plate diagrams occurs also in each of these species, accompanied more or less with intercalation of additional plates.

It then becomes evident that the discrimination of species of Holocystites, in the presence of numerous specimens, is likely to prove a matter of more or less difficulty, especially if specific differences be established chiefly on the general appearance of the plate diagram and the form of the theca as a whole. In such cases it is probable that a much safer guide will be found in the ornamentation of the individual plates of the theca, such as a central boss, radiating ridges, the presence, size, and arrangement of the granules, and the like. 
Further field-work in the stratigraphy of Anticosti Island during the past summer, leading to a revision of the lower part of the section, was then explained to the Society by the author, whose remarks were discussed by Messrs Schuchert, Vaughan, UTrich, and Chadwick.

\section{REVISION OF THE ANTIOOSTI SECTION}

BY W. H. TWENHOFEL

(Abstract)

The second formation of the Anticosti section is renamed the Vaurial from splendid exposures on the Vaurial River. The strata of Charleton Point, previously considered the type'locality of this formation, have been proven to belong to the English Head formation. The discovery of this fact greatly increases the size of the English Head fauna and shows it to have a stronger Richmond aspect than was suspected. Evidence has been discovered indicating an uplift of the Saint Lawrence region prior to the time of English Head deposition and a second period of uplift at the close of Ellis Bay time or the close of the Ordovician.

Luncheon time having arrived, the Society adjourned for an hour.

At 2 p. m. the afternoon session was opened with an appreciation by E. M. Kindle of the life and work of Mr. L. M. Lambe, late vertebrate paleontologist of the Canadian Geological Survey. A memorial of Mr. Lambe is presented on pages 88 to 97 of this Bulletin.

\section{REPORT OF THE AUDITING COMMITTEE}

The committee now announced that the Treasurer's accounts of the receipts and expenditures of the Society were found to be correct as read. It was then voted by the members that the report be accepted.

Vice-President Van Ingen now took the chair and the Society listened to the presidential address, which was illustrated with lantern slides.

\section{STUDIES IN VARIATION AND A PROPOSED CLASSIFICATION OF VARIANTS}

PRESIDENTAL ADDRESS BY ROBERT T. JACKSON

Following the presidential address, the vertebrate paleontologists withdrew and formed a section for the presentation of their own papers. The minutes of this section are printed on pages 222 to 225 .

The first paper on the general program was an interesting account, illustrated by lantern slides and drawings, of the peculiar fossil remains known as Serpulites. The paper was discussed by Messrs. Clarke, Foerste, Bassler, and the author, who presented diverging views as to the nature of these doubtful organisms.

XIV-Bull. Geot. Soc. AM., VoL. 31, 1919 


\title{
HYDROZOAN AFFINITIES OF SERPULITES SOWERBY
}

\author{
BY W. ARMSTRONG PRICE
}

\section{(Abstract)}

Serpulites MacLeay (erroneously attributed to Murchison by writers), a Ialeozoic genus, commonly provisionally placed with the tubicolous annelids. and to which have been referred conical tubes of a variety of form and composition, is restricted to chitinous tubes with marginal ridges appearing upon the flattened test. Several species formerly placed in the genus Enchostoma Miller are transferred to Serpulites.

A branching, tubular, plantlike organism from the Devonian of Paraná. Brazil, identical in the structure of individual tubes with tubes of serpulites, appears to be closely related to the latter, as has been pointed out by J. M. Clarke.

Ruedemann has enumerated points of resemblance between Serpulites and Conularia, among which are the possession by the young of both forms of terminal disks for attachment and the possession by both of longitudinal lidges, which he interprets in the case of Conularia and Serpulites as thickenings of the test.

An unflattened test referred to Serpulites from the Pennsylvanian of West Virginia is described, which shows two internal, cylindrical bodies, composed of galena and other crystalline materials, lying beneath the marginal regions where the "ribs," or ridges, are seen upon flattened specimens of serpulites.

The appearance of these marginal mineral deposits can not be considered to have a direct connection with the marginal ribs, if the latter are thickenings of the insoluble chitinous test. The suggestion has been offered that they may be replacements of internal structures composed of soluble materials, but no explanation of the presence of such problematical bodies is apparent. It is considered possible that the animal possessed two internal canals within the body tissue, and that, in the case of the specimen described, mineral sulphides and other salts were deposited in the canals in the presence of decaying organic matter. In the case of flattened specimens which show marginal welts in the flexible test, it is suggested that flattening took place before the complete decay of the animal body, and that the canals were more rigid than the intervening portion of the animal body.

If the latter interpretation should be confirmed by further investigation, the relation of Serpulites to the annelids would appear remote. The branching habit of the tubes and of the marginal ribs of the organism from Parani suggest a possible relationship with the Hydroids and Graptolites, in which case canals can be more readily understood. It is possible that the significance of the internal bodies may be ascertained by a further study of unflattened tests. These are found chiefly in limestone.

Following this paper Dr. Kindle gave a preliminary account of his work in the basin of the Lower Mackenzie River and described the salient faunal and stratigraphic features of the section, about 5,000 feet thick, ranging in age from Middle Silurian to Upper Devonian. Professor Schuchert, in discussing this paper, called attention to the important 
stratigraphic and paleogeographic results of Dr. Kindle's work in this far' northern area.

\title{
PALEOZOIC SECTION OF THE LOWER MACKENZIE RIVER
}

\author{
BY E. M. KINDLE
}

The last paper of the afternoon was an account of the Iowa Devonian echinoderms, given by the author and illustrated by numerous well selected lantern slides. It was discussed by Professor Jackson, who expressed his appreciation of the detailed studies of the author upon Iowa Devonian fossils.

\section{ECHTTODERMS OF' THE IOWA DEVONIAY}

\author{
BY A. O. THOMAS
}

\section{(Abstract)

The investigations of Hall, White, Whitfield, Barris, Wachsmuth and Springer, and others hare made known at least sixteen species of echinoderms collected in Devonian formations within the borders of Iowa.

The descriptions of the known forms are widely scattered through the literature; in this paper these are brought together and a few of the species are redescribed in the light of new material. A number of undescribed species in the Calvin Collection, together with several secured by the author during a study of the Iowa Devonian for the Iowa Geological Survey, brings the total number of species up to thirty. Four classes of echinoderms are represented, the most abundant being the crinoids. A brief analysis of the fauna follows.

The cystids are represented by two species of the genus Strobilocystites, one of them being new and differing from the other, S. calvini White, in having unbranched ambulacra, nodose ambulacral plates, and smooth thecal plates. These cystids occur in the Cedar Valley limestones and are relatively rare.

The blastoids include one pentremite, Pentremitidea subtruncatus (Hall), and three species of Nucleocrinus. Two of the latter are described by Barris in the Proceedings of the Davenport Academy of Science, and the third is new. The new species has a large calyx, which in cross-section is sharply stellate, and its very narrow ambulacra are elevated upon the longitudinal keel-like edges.

The crinoids, especially the camerates, are rery common and in places their remains make a crinoidal limestone. Of the Melocrinidæ there are five species of Melocrinus; these are M. nodosus Hall, from near Iowa City; M. tiffanyi Wachsmuth and Springer, from Solon; a new species with extremely nodose plates from Brandon, and another with a large bowl-shaped cup and smooth plates from Rockford. Dolatocrinus triadactylus Barriš, stereocrinus triangulatus Barris, and a new Stereocrinus from Littleton with stout spines on the costals complete this family. The Batocrinidæ are abundantly represented by the well known Megistocrinus farnsworthi White. M. latus Hall and $M$. nodosus Barris are much less common. The Hexacrinidæe include the type and only specimen of Hexacrinus occidentalis Wachsmuth and Springer from 
Davenport and a new, fairly large species from the Cedar Valley near Rockford. In the latter the two primibrachs are separate-a point which proves to be an exception in this rare North American genus. Arthracantha, which is found in the Hamilton, Portage, and Chemung of the Lake Ontario region, is represented by fragmentary remains from the Independence shale near Brandon.

The Flexibilia are rare. A new species assigned tó Dactylocrinus is founded on a well preserved specimen from the Lime Creek shale at Bird Hill. It is close to D. concavus (Rowley) from the Craghead Oreek shale near Fulton, Missouri, but has a granulose surface. The only other flexible crinoid is Taxocrinus interscapularis Hall from Buffalo.

Two species of Inadunata, Synbathocrinus matutinus Hall and Deltacrinus barrisi (Worthen), have been described from beds at Buffalo and Davenport respectively. A new form of Decadocrinus from Vinton, preserving the crown, and some imperfect specimens of Cyathocrinus and of a doubtful Lecanocrinus from the Lime Creek shale conclude this order.

The class Echinoidea contain very unique remains and they are abundant in certain zones in the Lime Creek shale. Unfortunately, the plates and spines of the tests are dissociated, but are still in such close proximity that little error, it is felt, is made in referring the separate parts to their approximate position in the test. Moreover, the various species have not been found commingled, but at different horizons and localities. Three genera, two of them new and the other hitherto unknown, from North America are recognized. They belong to the family Archæocidaridæ. Devonocidaris has small, remarkably thin, and fragile interabulacral plates, bearing a central tubercle and a few secondary tubercles; a scrobicule is fairly well defined and a basal terrace is present. Spines long and acicular. Teeth, braches, and other parts of the lantern well preserved. Xenocidaris, described by Schultze from the Devonian of Germany, is represented by a considerable number of trumpet- or clubshaped spines, whose slender shafts terminate distally in flat or concave apices surrounded by a marginal coronet of blunt spinules. These spines are specifically distinct from the Eifel species. The third genus is named Nortonechinus. Its heavy interambulacral plates are highly imbricate, indicating that the test had considerable flexibility. The primary spines are stout and they expand distally, until over the greater part of the test they are rendered polygonal by mutual contact; their apical faces are flat. These spines formed a protective covering over the test much as to the expanded spines of Colobocentrotus atratus Brandt of our modern seas. Ambulacral plates and the parts of the lantern are also preserved.

At 5.30 the Society adjourned for the day. In the evening the members participated in the annual dinner with the Fellows of the Geological Society of America. 


\section{SYMPOSIUM ON TEACHING OF PALEONTOLOGY}

\section{Session of Wednesday, December 31}

It 9 a. m. the Society met in general session with the Geological Society of America, to participate in the symposium on the teaching of geology and paleontology. The papers in this symposium by members of the Paleontological Society were as follows:

Charles Schuchert: American paleontologists and the immediate future of paleontology.

J. C. Merriam: The teaching of paleontology as fundamental to history, the humanities, and science.

H. F. Cleland: The general teaching problem of paleontology.

E. W. Berry: The teaching of paleobotany.

Stuart Weller: The teaching of invertebrate paleontology.

R. T. Jackson: The value and use of stages of development in teaching.

\section{CONTINUATION OF PALEONTOLOGIC PAPERS}

With the conclusion of the symposium, at 12.30 p. m., the Society adjourned for luncheon, convening again at 2 p. m., to continue the reading of papers, in two sections. Vice-President Van Ingen was chairmau of the Section of Invertebrate Paleontology, while Mr. Granger continued as chairman of the Vertebrate Section.

In the Invertebrate Section the first paper of the afternoon was an account of bibliographic catalogue of Cambrian fossils of the world under preparation by the author, who explained the various phases of the work.

\section{BIBLIOGRAPHIO STUDIES OF THE CAMBRIAN}

BY CHARLES E. RESSER

\section{(Abstract)}

Because of the scattered nature of Cambrian data, much of which is inaccessible to many workers, it seemed advisable to work out and publish a summary of all available information. Such a work was begun several years ago and is now nearing completion. It comprises a bibliography of all papers on the Cambrian and a bibliographic synomony of the fossils, in the first part. The second part will consist mainly of a summary description and discussion of each Cambrian formation, taken up in a geographic order and with a list of the fossils. A correlation table of all formations will also be included.

Intercontinental correlations and the faunal similarities and identities of the Middle Cambrian rocks of Newfoundland and Great Britain were next presented by the author, who illustrated his remarks by charts. Discussed by E. O. Ulrich. 


\section{CORRELATION OF THE MIDDLE CAMBRIAN OF NEWFOUNDLAND AND GREAT BRITAIN}

BY B. F. HOWELL ,

\section{(Abstract)}

Recent discoveries in Great Britain and southeastern Newfoundland indieate that the faunal succession of the Paradoxides beds of those two regions is remarkably similar. The three faunas occurring in Newfoundland, which are characterized by Paradoxides bennetti, $P$. hicksi, and $P$. davidis, are represented in Great Britain by the faunas characterized by $P$. groomi, $P$. hicksi, and $P$. davidis. A great many of the British species are represented in Newfoundland by nearly or quite identical forms with very similar ranges. As most of the Scandinavian faunas are represented in the British sections, and as most or all of the Massachusetts and New Brunswick faunas occur in Newfoundland (the Massachusetts Paradoxides harlani fauna, at the bottom of the Newfoundland section, the New Brunswick faunas, somewhat higher up), the relations between the northeastern North American and the northwestern European beds are now fairly well understood. Much work still remains to be done in both Great Britain and Newfoundland, and when this is completed we shall probably be able to correlate the beds of the two countries in even greater detail than at present.

The recent discoveries do not appear to throw much new light on the problems of the place or places of origin and the migrations of the Paradoxides faunas, but they do seem to prove conclusively that there was an easy route of migration between the British and Newfoundland regions during a large part of known Paradoxides time.

A third contribution dealing with the Cambrian followed, consisting of a description of the Upper Cambrian stratigraphy of Wisconsin, the faunal relations of the various formations, and the paleogeography of the time. This paper, presented by the author and illustrated by diagrams and charts, was discussed by P. E. Raymond.

CAMBRIAN FORMATIONS AND FAUNAS OF THE UPPER MISSTSSIPPI VALLEY

BY E. O. ULRICH

New views on the body structure of the trilobites, resulting from the author's recent researches, were then explained and illustrated by lantern slides.

\section{TRILOBITES AS ANCESTORS}

BY PERCY E. RAYMOND

(Abstract)

When the appendages of modern Arthropoda are compared with those of trilobites, it is found that the latter represent a simple type from which it is possible that all others were derived. Analysis shows that the phyllopodan 
limb is not primitive, and that the modern Branchiopoda are not so nearly allied to the trilobites as the Copepoda are. Relationships to the Arachnida, Diplopoda, Chilopoda, and Insecta are pointed out. A renewed study of the bodily form of the trilobite shows that it is not so specialized as has been supposed, and that it is capable of modifications which allow a consideration of these animals as the possible ancestors of the other Arthropoda.

The results of studies on the formation of coquina followed, with the author's remarks illustrated by lantern slides. Discussed by Dr. T. Wayland Vaughan, with replies by the author.

ORIGIN OF THE "BEACH ROCK” (COQUINA) AT LOGGERHEAD KEY, TORTUGAS

BY RICHARD M. FIELD

(Abstract)

Through the kindness of Dr. Alfred G. Mayer, the writer was enabled to visit the Tortugas group for the purpose of studying the conditions of sedimentation on and near the "coral" reefs. Among other studies, an attempt was made to discover the origin of the "beach-rock" or cemented shell-sands which occur between high and low'tides. By means of a stand-pipe and pump, it was found that during heavy rains a shell key acts like a reservoir, and that the meteoric water (to which an appreciable amount of humus acid is added as it passes through the surface layers) dissolves $\mathrm{CaCO}_{3}$ on its way down through the loose shell sands. The ground water, which lies just above the salt or brackish water zone, was found to contain 40 per cent more $\mathrm{CaCO}_{3}$ in solution, or colloidal suspension, than the normal sea water. This concentrated solution of $\mathrm{CaCO}_{3}^{\circ}$ has a strong cementing value, and is probably an important factor in the formation of the "beach-rock" where the ground water flows out through the beach sands, between tides.

A curious similarity of foraminifera in the Upper Vicksburgian of Mississippi and the recent waters of the Indo-Pacific region formed the subject of the next paper.

FORAMIVIFERAL FAUNA OF THE BYRAM MARL

BY JOSEPH A. CUSHMAN

(Abstract)

A study of the foraminifera of the marl at the type station Byram, Mississippi, has shown a fauna consisting of nearly seventy (70) species. Nearly half of these are undescribed; of the others most of them are either now living or represented by a closely allied species in the shallower waters of the IndoPacific region. Some of the species are also found in the Mint Spring marl and in the Red Bluff clay, the lower members of the Lower Oligocene.

Dr. Vaughan next presented a digest of his stratigraphic studies on certain parts of the West Indies and Central America, illustrating his remarks by lantern slides. 
STRATIGRAPHY OF THE VIRGIN ISLANDS OF THE UNITED STATES AND OF

CULEBRA AND VIEQUES ISLANDS

BY THOMAS WAYLAND VAUGHAN

\section{(Abstract)}

The following are the conclusions expressed in this paper:

(1) The presence of shoal water deposits of Upper Cretaceous age, in Saint Croix and in the islands on the Virgin Bank from Saint John to Porto Rico and in Porto Rico, shows that the major tectonic axis of this part of the West Indies antedates Upper Cretaceous time, because there was an antecedent basement on which these deposits were laid down. I have recently suggested that these major trends may be even as old as late Paleozoic.

(2) During Upper Cretaceous time it is probable that most, perhaps all, of the areas now occupied by land were under water, and that there was considerable volcanic activity is proven by the water-laid tuffs and lava, flows which are interbedded with the shoal-water calcareous sediments.

(3) In early Tertiary, probably Eocene, time there was mountain-making by folding, which in places was so intense that the stratified rocks were left in an almost vertical position, and both the sediments and the older igneous rocks were highly metamorphosed. There were also intrusions of diorite, dolerite, and granite, and probably the extrusion of some volcanic rocks. West of the Virgin Islands, there was during later Eocene time extensive submergence in Santo Domingo, Haiti, and Cuba, as is attested by the Upper Eocene limestones now above sealevel in those areas.

(4) The episode of mountain-making was followed in the Virgin Islands by one of prolonged subaerial erosion, and the production of the Virgin Bank apparently may in large part be assigned to this period of the history of the region. It seems that the axial islands on the Virgin Bank and the Central Sierras of Porto Rico, from its east to its west end, have continuously stood above the water since the close of Cretaceous deposition. In Saint Croix by Middle Oligocene time erosion had proceeded far enough to reduce almost to baselevel the tightly, steeply folded strata of the mountains.

(5) In Middle Oligocene time a large part of Saint Croix was submerged and, with slight fluctuations, remained under water until some time during the Miocene. Although both the northern and southern, but not the axial, parts of western Porto Rico were submerged in Middle Oligocene and probably in Lower Oligocene time, the eastern end of Porto Rico and the axial islands of the Virgin Bank west of Anegada Island were not submerged. The age of the limestone on Anegada Island is not known. These facts mean that there was differential movement, the movement being greater toward the west than in the central part of the bank. In Lower Miocene time the northern shore of Porto Rico east of San Juan was submerged, as were also the southern shore and eastern end of Vieques Island; both the northern and the southern edges of the bank were submerged probably by marginal down-flex- 
ing. Although there are corals in the exposed sediments of Oligocene and Miocene age, and corals were therefore constructional agents during those epochs, their work, as compared with that of other agents, was of minor importance. If the work of these organisms in forming deposits concealed under water can be evaluated by their rork in deposits exposed to view, the conclusion would be drawn that they played only a minor rôle in the formation of the Virgin Bank. There is as yet no evidence showing intense deformation during later Oligocene time in the Virgin Islands and Porto Rico, such as is known to have taken place in Santo Domingo.

(6) Subsequent to early Miocene time there has been uplift, greater along the axis of Porto Rico and the Virgin Bank than on the flanks, bringing Miocene and older Tertiary sediments, in places where they are present, above sealevel. The Tertiary sediments are tilted and gently flexed, but they have not been deformed as the Upper Cretaceous deposits. It is about this time that the land connections permitting migration of land animals from Anguilla to Porto Rico, Haiti, and Cuba seem to have existed. Saint Croix seems to have been connected with Anguilla, Saint Martin, and Saint Bartholomew.

(7) The period of high stand of land was followed by an episode of blockfaulting, such as I have several times described recently. By faulting, Anegada Passage between the Virgin Bank and Anguilla was produced, and the islands assumed very nearly the outlines and arrangements of today.

(8) Subsequent to the episode of faulting, there was emergence of the land and terracing of the margins of the Virgin Bank, followed by submergence. In places in Porto Rico and along the Cordilleras reef, which extends eastward from the northeast corner of Porto Rico, there has been local emergence due to differential crustal movement.

(9) The living coral reefs on the Virgin Banks are growing on an extensive flat in a period of geologically Recent submergence. This flat is geologically an old feature. Its origin, in large part at least, may reasonably be attributed to the long period of erosion following early Tertiary mountain-making.

There was then presented a stratigraphic paper transferred from the program of the Geological Society of America:

\section{GEOLOGIO RECONNAISSANCE IN SANTO DOMINGO}

BI C. WYTHE COOKE

\section{(A Astruct)}

During the spring and early summer of 1919 a preliminary reconnaissance of Santo Domingo was made for the Dominican Government by T. W. Vaughan, D. D. Condit, C. P. Ross, and the writer, under the direction of Dr. Vaughan. The central mountain system was crossed by three routes and as much of the areas north and south of it was examined as was feasible in the time allotted. Many fossils, chiefly from the Tertiary formations, were collected, and have been distributed to specialists for study. The data obtained, al-

I Published by permission of the military governor of the Dominican Republic. 
though incomplete, are sufficiently exact to block out the major features of the topography and geology.

The Cordillera Central, a rugged mountain system, extends from the eastern end of the island westward into Haiti. It is flanked on the north by the Cibao Valley, a fertile valley extending from Samana Bay to Manzanilla Bay. The Cordillera Setentrional, containing some peaks 4,000 feet high, lies between the Cibao Valley and the Atlantic. South of the Cordillera Central a coastal plain borders the Caribbean as far west as Calderas Bay. The Ażua Flain and the great Valley of San Juan separate the Cordillera Central from the mountains of the Sierra de Neiba and the Sierra de Martín García. Lake Enriquilio, 144 feet below sealevel, occupies part of the depression called the Enriquillo Basin, between the Sierra de Neiba on the north and the Sierra de Bahoruco on the south. Little is known of the southern peninsula.

The basal complex, consisting chiefly of metamorphic and igneous rocks, is similar to the corresponding formations of Cuba, Porto Rico, and the Virgin Islands. It makes up a large part of the Cordillera Central and Samana Peninsula. Rocks of known Cretaceous age occur in the southern part of the Cordillera Central, between Santo Domingo City and Azua, and in the faulted front range of the Cordillera Setentrional near Demajagua.

The Tertiary formations and their supposed equivalents are named in the correlation table. All the names of Dominican formations in the table are new except the Cercado formation and the Gurabo formation, which were very recently proposed by Dr. Maury. ${ }^{2}$ Lower and Middle Eocene sediments appear to be lacking in Santo Domingo, but from Upper Eocene upward there is a nearly complete sequence. Iimestone of Upper Eocene age is widely distributed on both sides of the Cordillera Central, but appears' to be roost extensively developed in the mountains of Barahona Province. Two formations of Oligocene age in the north have been given names, and rocks of the same age have been found also in the south. The Lower and Middle Miocene are represented by the thick series of conglomerates, silts, and coralliferous limestones comprising the Yaque group, and the upper Miocene, not at present known elsewhere in the West Indies, appears to have left its trace in the gypsum, salt, and clastic sediments of the Las Salinas formation. The Las Matas gravels are supposed to be of Pliocene age, but no fossils have been found in them.

Pleistocene deposits--gravels, soft limestones ("caliche"), and raised coral reefs and beaches-are widely distributed around the island.

In addition to rocks of igneous origin included within the basal comṕlex, there is a considerable variety of eruptive and dike rocks, tuffs, and agglomerates, the youngest of which is not older than Pleistocene. These late igneous rocks are most conspicuons in the Province of Azua.

Faults are numerous and outline many of the topographic features. Folding, except in the basal complex, is less important.

\footnotetext{
${ }^{2}$ C. I. Maury : Science, new series, volume 50, December 26, 1919, page 591.
} 


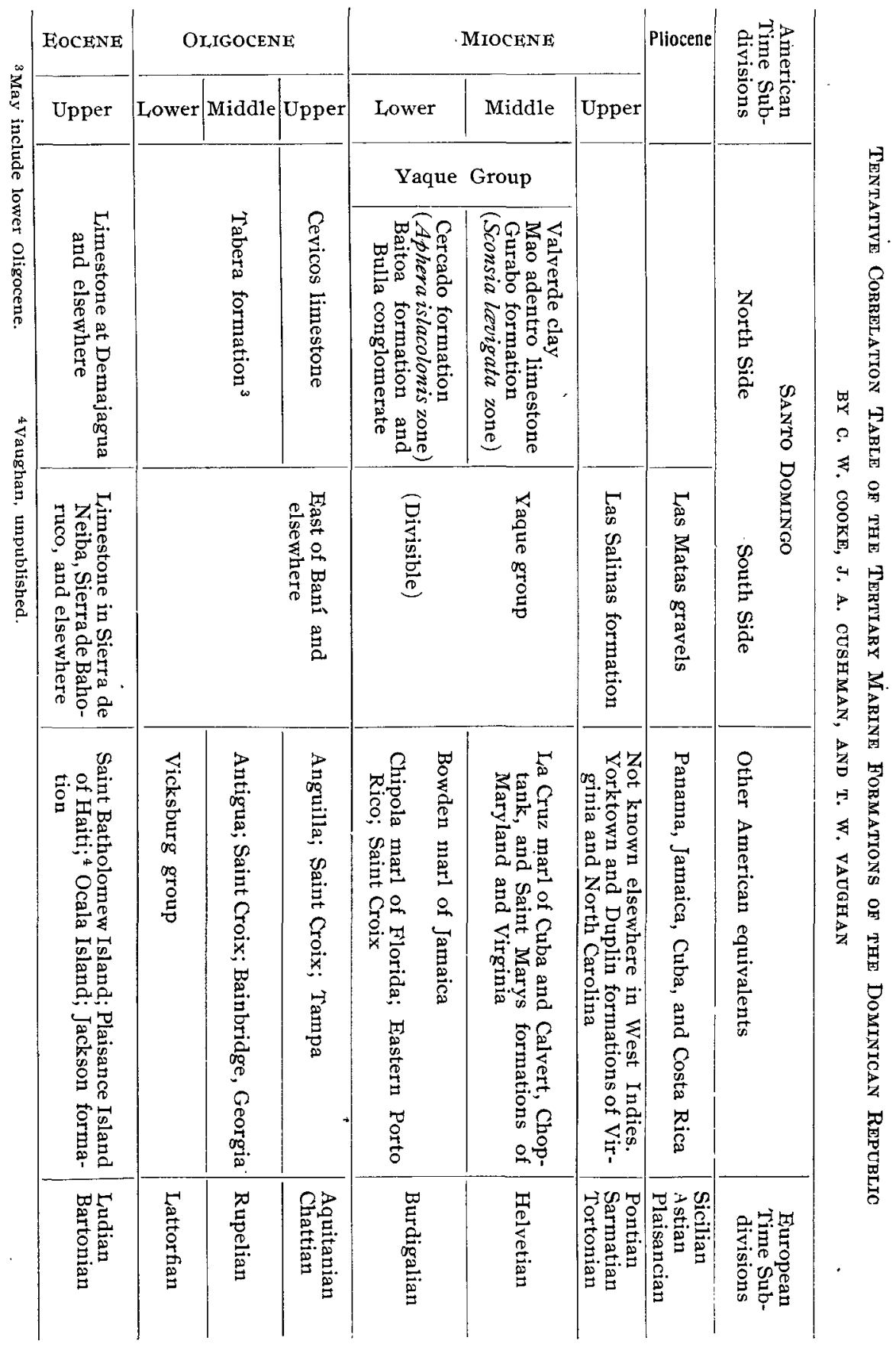


A paper explaining the laboratory method of teaching paleobotany at Brown University was then delivered by the author, who illustrated he! remarks with copies of a laboratory manual prepared by her for the purpose and distributed among the members.

NOTES ON THE TEACHING OF PALEOBOTANY

BY MARION D. WESTON ${ }^{1}$

A study of the growth of the arms in the cystid genus Caryocrinites, illustrated by lantern slides, was then presented by the author under the title

METHOD OF APPEARANCE OF ADDITIONAL ARMS ON INCREASING AGE IN

- CAŔYOCRINITES

BY A. F. FOERSTE

(Abstract)

The youngest known specimens of Caryocrinites ornatus Say from the Rochester shale of New York possess three subtegminal food grooves, each terminating in a single arm. Older specimens may possess 14 or more well developed biserial arms at the ends of a corresponding number of branches of the subtegminal food groove system. From this it is evident that the food grooves branch within the theca, beneath the tegmen, and that there is some method by which the food grooves pass through the theca and reach the surface. On examining each articulating surface at which an arm was attached to the theca, this is found to rest on three small plates at the margin of the tegmen, the passage for the food groove being at the junction of the three plates. A second passage, much smaller in size and apparently representing the axial canal, is located a short distance farther down, between the two lower plates forming the articulating surface.

Few specimens retain the arms. Usually only the articulating surfaces for their attachment are observed.

In addition to the articulating surfaces for the attachment of the arms, practically all specimens, both old and young, possess small depressions in their immediate vicinity. At the base of each of these depressions there is a small passage located between two of the marginal plates of the tegmen and connecting with the food-groove system. The larger of these depressions frequently are marked along the median line by a single low ridge, arranged in a radial direction and suggesting the former attachment here of some small arm or armlike appendage. The smaller depressions show no evidence of articulation with anything.

The earlier of these depressions usually appear in accordance with a readily recognized system. In the youngest known specimens, with only three distinct arms, one depression makes its appearance on the sinistral side of each of

\footnotetext{
${ }^{1}$ Introduced by R. S. Bassler.
} 
the three primary arms; later an additional depression is found on the dextral side of each arm. Each depression is connected with the food-groove system. by a pore passing between two or three of the marginal plates of the tegmen. At first, the depressions show no evidence of articulation with anything. Later, as they grow in size, the articulating ridge mentioned in the preceding paragraph makes its appearance. Still later, articulating surfaces for the attachment of full-sized arms are found where younger specimens show only depressions, but in the meantime additional small depressions appear along. some of the neighboring sutures between the more or less marginal plates of the tegmen, and the latter, in time, also developing articulating ridges and: then articulating surfaces, until 14 or more articulating surfaces for fullsized arms are present.

In this process it is probable that well developed arms with biserially arranged plates were accompanied by much smaller arms with plates in their more initial stages; and the still younger arms, at their first appearance exterior to the theca, may have been free from protective plates altogether.

Since even the largest and most mature specimens of Caryocrinites show depressions in addition to the articulating surfaces for fully developed arms, it is possible that some of the later developed arms functioned genitally and did not serve merely for the conveyance of food.

The argument for the recognition of the Paleocene as a distinct epoch of the Tertiary was presented briefly by the author.

\section{STATUS AND LIMITS OF THE PALEOCENE}

BY W. D. MATTHEW

\section{(Abstract)}

The term Paleocene has been revived by several vertebrate paleontologists: in recent years to cover the faunal zones previously known as Basal Eocene. Upon evidence of the vertebrate faunas it is entitled to rank as a distinct epoch, coordinate with the Eocene and Oligocene. It includes the Puerco, Torrejon, Fort Union, and probably certain less known vertebrate faunas in. this country, and the Cernaysian in France. Its upper limit is marked by the first appearance of the principal modern orders of mammals and of certain modern groups of reptiles simultaneously in Western America and in Western Europe. The lower limit is more doubtfully fixed by the first appearance of placental mammals. The evidence of marine invertebrates and of plants does not at present appear to support the distinction of the Paleocene as a separate epoch. It is possible, however, that it covers the gap between the Cretaceous and Tertiary insisted upon by many stratigraphers and paleobotanists, and there are other possible interpretations that might reconcile the evidence. The writer believes that the epoch may also prove to include the Lance and certain other dinosaur-bearing formations, and that it may belong rather to. the Cretaceous than to the Tertiary period. No final conclusions are in orderintil the evidence in different fields has been satisfactorily reconciled. 
STUDY OF THE LIFE PROCESSES IN FOSSILS

BY R. S. BASSLER

'The last paper of the session was a short discussion of the methods of recognizing the life processes in fossils, and of the importance of taking these factors into account in the discrimination of species. The remarks were based mainly upon the cyclostomatous bryozoa, where species exactly alike externally show by their ovicells, or organs of reproduction, that they belong far apart.

The following papers were read by title:

SPONGES OF THE MIDDLE CAMBRIAN

BY CHARLES D. WALCOTT

INORGANIC EVIDENOES OF DISCONFORMITIES IN LIMESTONE

BY RICHARD M. FIELD

At 5.30 the Society adjourned.

\section{Minutes of Sectional Meeting of Vertebrate Paleontology}

The section convened at 3.30 p. m. Tuesday, December 30 , at the conclusion of President Jackson's address, with Walter Granger as chairman and Messrs. Matthew, Gregory, Camp, Lull, Loomis, Troxell, Thorpe, Chaney, Sinclair, Stock, and Buwalda present.

The following papers were then presented, the first one, on paleobotany, being included in this section on account of relationship to the rertebrate faunas of the same region:

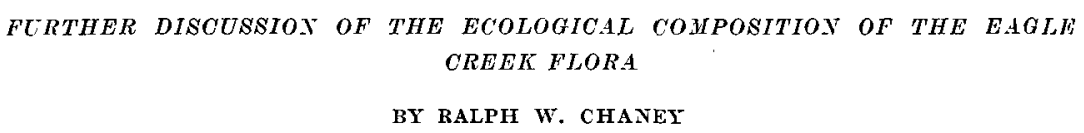

The Eagle Creek flora of the Columbia Gorge region is made up largely of dicotyledonous arboreal forms, and the flora as a whole bears a strong resemblance to that now occupying the northeastern United States. Its most notable feature is a mixture of mesophytic and xerophytic types, the former dominating in number of species, the latter in number of individual leaves. This mixture is interpreted as being due to a raried topography during the Eagle Creek epoch-an interpretation which suggests a bajada mode of origin for the Eagle Creek formation. 


\title{
NEW MOUNTS IN THE PRINCETON GEOLOGICAL MUSEUM
}

\author{
BY WJLEIAM J. SINCLAIR
}

\section{(Abstract)}

Lantern slides illustrating mounted skeletons of the Bridger Eocene creodont Mesonyx obtusidens and the White River Oligocene cursorial rhinoceros, Hyracodon nebrascense, were exhibited. These mounts, of the most modern panel type, are of interest because they embody the only practically complete skeletons of both animals yet known. The material is not new. The Mesonyx skeleton was found in 1885 and the Hyracodon skeleton ten years later, and both have been described at length by Prof. W. B. Scott. The new mounts bring out the highly cursorial character of these animals. In bodily proportions, Mesonyx closely resembles a modern wolf, differing, of course, in the shape of the head and in the structure of the feet, while Hyracodon approaches, in its limb structure, some of the larger three-toed horses of the Cpper Oligocene and would, undoubtedly, have been monodactyl, like the modern horse, had its line persisted.

\section{STCDY OF THE ENTELODONTS \\ BY EDW ARD L. TROXELL}

\section{(Abstract)}

A summary of the features of several new species of entelodonts in the Marsh Collection. It is argued that the wear of the teeth indicates a complex movement of the mandible, and that this is made possible by the use of the peculiar processes from the jaw and molar arch, which are so characteristic of the family.

\section{MOUNTED SKELETON OF MOSCHOPS CAPENSIS BROOM}

BY WILLIAM IF, GREGORY

\section{(Abstract)}

This dinocephalian reptile from the Permian of South Africa is repre: sented in the American Museum collections by the remains of numerous skeletons, all more or less incomplete, found in one locality by Dr. Broom in 1910 .

When sorted according to size and age by Dr. Broom, it was found that three of the individuals afforded knowledge of the principal elements of the adult skeleton. The missing parts of one of these lave since been carefully restored and the whole animal has been mounted for exhibition. Remarks were made on other dimocephalian genera and on the characters of the group as a whole.

SMALL MAMMALS IN THE MARSH COLLECTION AT YALE UNIVERSITY BY EDWARD L. TROXELL

\section{(Abstract)}

Three Oligocene specimens of unusual interest were illustrated by lantern slides and briefly discussed. Hypisodus sp.? is a very small deer with many 
very progressive characters, but of uncertain taxonomic position. Ictops dakotensis and Palcologus haydeni are represented by skulls and skeletal parts which, because of their perfection, will add to our knowledge of these tiny creatures.

\title{
TERTIARY ARTIODACTYLS FROM THE MARSH COLLECTION
}

\author{
BY RICHARD S. LULI.
}

\section{(Abstract)}

Numerous remains of a small horned antelope, apparently new to science, collected by the Yale Museum expedition of 1914 in western Nebraska, are described, together with a novel method of combining the mounted skeleton of the animal with the plastic restoration in the flesh. No characters appear which debar this form from direct ancestry with the existing prong-buck, Antilocapra. A new species of Blastomeryx, contemporaneous with the above, of which the type skull was collected by Professor Marsh in 1872, is also described.

At 5.30 p. m. the section adjourned for the day.

On Wednesday, December 31, the sectional meeting was resumed at $2.30 \mathrm{p.} \mathrm{m}$. and the following papers were presented:

\section{OLIGOCENE EQUIDAE IN THE MARSH COLLECTION}

\author{
BY JOHN P. BUWAIDA
}

\section{(Abstract)}

A preliminary statement indicating that the Oligocene Equidx material in the Marsh collections, derived from the John Day region of eastern Oregon and from the Great Plains, and consisting of several complete skulls and a considerable quantity of teeth and partial jaws, represents about half of the described species of Mesohippus, Miohippus, and Archeohippus. At least two forms are recognized as new. The genus Mesohippus appears to grade insensibly into the genus Miohippus in the material studied.

\section{PAWNEE CREEK BEDS OF COLORADO}

BY F. B. LOOMIS

\section{(Abstract)}

This paper takes up the position of the Pawnee Creek Beds in the series and particularly points out that they should be divided into a lower bed, "Pawnee Creek," and an upper level, which is of Pliocene age.

NEW SPECIMEN OF THE PLEISTOCENE BEAR ARCTOTHERIUM FROM TEXAS BY W. D. MATTHEW

\section{(Abstract)}

A specimen found by C. H. Sternberg, during the past season, in. the Rock (reek formation, Briscoe County, Texas, two miles north of the famous 
Equus quarry discovered by J. W. Gidley. It consists of the hinder half of the skeleton, very perfectly preserved, which exceeds in size the largest living brown bears. The specimen has recently been acquired by the American Museum.

NOTHROTHERIUM SHASTENSE, A PLEISTOCENE GROUND SLOTH OF NORTH AMERICA, WITH REMARKS ON THE MEGALONYCHIDAE

BY CHESTER STOCK

At 4 p. m. the section adjourned and resumed meeting wth the general Society.

Register of the Boston Meening, 1919. .

Anderson, Robert

BASSLER, R. S.

BELI, W. A.

Burling, L. D.

Buwalda, JoHN P.

Chadwick, G. H.

Chaney, R. W.

Clarke, J. M.

Cleiland, H. F.

Coоke, C. W.

Coryeli, H. N.

Cushman, J. A.

Freld, R. M.

Foerste, A. F.

Galloway, J. J.

GoldRING, W.

Gordon, C. E.

Grabau, A. W.

Granger, Walter

Gregory, W. K.

Hartnagel, Chris

Haynes, W. P.

How ELL, B. F.

Hyde, Jesse

I $\Lambda$ CKSON, R. T.
JefFrey, E. C.

KINDLE, E. M.

LEE, W. T.

LoomIs, F. B.

LULI, R. S.

Matthews, W. D.

Merria M, J. C.

O'Conneli, M.

Price, W. A.

Raymond, P. E.

Resser, C. E.

Schuchert, C.

ShImer, H. W.

Sinclair, W. J.

Stock, C.

Talbot, M.

Thomas, A. 0.

Thorpe, M. R.

Troxeld, E. T.

TwENHOFEL, W. H.

Twitchell, M. W.

UIRTCH, E. 0 .

VAN INGen, G.

VAUGHAN, T. W. 


\section{OFFICERS, CORRESPONDENTS, AND MEMBERS OF THE: PALEONTOLOGICAL SOCIETY}

OFFICERS FOR 1920

President:

Frederick B. Loomis, Amherst, Mass.

First Vice-President:

E. C. Case, Ann Arbor, Mich.

Second Vice-President:

Ralph Arnold, Los Angeles, Calif.

Third Vice-President:

Edward M. Kindle, Ottawa, Canada

Secretary:

R. S. BAssLeR, Washington, D. C.

Treasurer:

Richard S. Lulu, New Haven, Conn.

Editor:

W. D. Matrinew, New York City

MEMBERSHIP, 1920

CORRESPONDENTS

Nathorst, Dr. A. C., Royal Natural History Museum, Stockholm, Sweden.

Buckman, S. S., Esq., Westfield, Thame, England.

Déperet, Prof. Charres, University of Lyon, Lyon (Rhone), France.

Woodwakd, Dr. Henry, British Museum (Natural History), London, England.

MEMBERS

Adams, L. A., State Teachers' College, Greeley, Colo.

Aguilera, Jose G., Instituto Geologico de Mexico, City of Mexico, Mexico.

Aldrich, Truman H., 1036 Glen Iris Avenue, Birmingham, Ala.

AMr, Henry M., Geological and Natural History Survey of Canada, Ottawa, Canada.

ANderson, F. M., 2604 Etna Street, Berkeley, Calif.

Anderson, Robert, 47 Parliament St., Westminster, S. W. I., London, England. Armstrong, Edwin J., 954 West Ninth Street, Erie, Pa.

ARNoLd, RALPh, 921 Union Oil Building, Los Angeles, Calif.

Bagg, Rufus M., JR., Lawrence College, Appleton, Wis. 
Baker, Charles L., Bureau Economic Geology and Technology, University of Texas, Austin, Texas.

Barbour, Erw in H., University of Nebraska, Lincoln, Nebr.

Barrows, Albert L., 1201 16th Street, Washington, D. C.

Bartsch, PaUl, U. S. National Museum, Washington, D. C.

Bassler, Harver, U. S. Geological Survey, Washington, D. C.

Bassler, Ray S., U. S. National Museum, Washington, D. C.

Beede, Joshua W., 1711 San Antonio Street, Austin, Texas.

Bell, Walter A., $81 \mathrm{Elm}$ Street, St. Thomas, Ontario, Canada.

Benstex, B. A., University of Toronto, Toronto, Canada.

Berckhemer, Fritz, Department of Paleontology, Columbia University, New York City.

BerRy, EDWARD W., Johns Hopkins University, Baltimore, Md.

Bibiins, Arthur B., Woman's College, Baltimore, Md.

Billings, Walter R., 1250 Bank Street, Ottawa, Canada.

Bostw Ick, Thomas A., 43 Livingston Street, New Haven, Conn.

Bra N'son, E. B., University of Missouri, Columbia, Mo.

Brown, Barnum, American Museum of Natural History, New York City.

Brown, Thomas C., Laurel Bank Farm, Fitchburg, Mass.

Bryant, William L., Buffalo Society of Natural History, Buffalo, N. Y.

Burling, Lancaster D., Geological Survey of Canada, Ottawa, Canada.

ButTs, Charles, U. S. Geological Survey, Washington, D. C.

Buwalda, John P., Hopkins Hall, Yale.University, New Haven, Conn.

Case, Ermine C., University of Michigan, Ann Arbor, Mich.

Chadwck, Geonge H., University of Rochester, Rochester, N. Y.

Clark, Bruce L., University of California, Berkeley, Calif.

Clarke, John M., Education Building, Albany, N. Y.

Cleland, Herdman F., Williams College, Williamstown, Mass.

Clements, F. E., Desert Laboratory, Tucson, Ariz.

Cooke, C. Wythe, U. S. Geological Survey, Washington, D. C.

Coor, Harold J., Agate, Nebr.

Crane, Will E., 208 13th Street N. E., Washington, D. C.

Cumings, Ė̉gar R., Indiana University, Bloomington, Ind.

Cushman, Joseph A., Sharon, Mass.

Dall, W. H., U. S. National Museum, Washington, D. C.

Dean, Bashford, Columbia University, New York City.

Dice, Lee Raymond, Dept. of Zoology, University of Illinois, Urbana, Ill.

Drckerson, Roy E., 114 Burnett Arenue, San Francisco, Calif.

Doneghy, John T., 5618 Clemens Avenue, St. Louis, Mo.

Douglass, Earl, Carnegie Museum, Pittsburgh, Pa.

DuBois, Henky M., Box 539, La Grande, Oreg.

Dunbar, Carl O., University of Minnesota, Minneapolis, Minn.

Eaton, George F., 80 Sachem Street, New Haven, Conu.

Eyerman, John, "Oakhurst," Easton, Pa.

Field, Richard M., 16 Alvester Street, Jamaica Plains, Mass.

Foerste, August F., 129 Wroe Avenue, Dayton, Ohio.

Frick, Chinds, 70th and Central Park, New York City.

Galloway, J. J., Department of Geology, Columbia University, New York City.

GardNer, Julia A., Department of Geology, Johns Hopkins University, Baltimore, Md. 
Gester, G. S., Standard Oil Building, San Francisco, Calif.

Gibr, Hugh, Peabody Museum, Yale University, New Haven, Conn.

GiLbert, J. Z., Los Angeles High School, Los Angeles, Calif.

Gordon, Clabence E., Massachusetts Agricultural College, Amberst, Mass.

Gould, Charles N., 408 Terminal Building, Oklahoma City, Okla,

Grabau, Amadeus W., Columbia University, New York City.

Granger, Walter, American Museum of Natural History, New York City.

GrEenE, F. C., 30 N. Yorktown Street, Tulsa, Okla.

GREGoRY, W. K., American Museum of Natural History, New York City.

Grier, Norman McD., 718 Clara Avenue, St. Louis, Mo.

GordRIng, Winifred, Education Building, Albany, N. $\mathbf{Y}$.

Gurdey, Wildiam F. E., 6151 University Avenue, Chicago, Ill.

Guintylıo, John A., University of California, Berkeley, Calif.

Hamuin, Homer, 1021 South Union Avenue, Los Angeles, Calif.

Hannibal, Harold, Stanford University, Stanford, Calif.

HarRis, Gilbert D., Cornell University, Ithaca, N. Y.

Hartnagel, Chris A., Education Building, Albany, N. Y.

HaYnes, Winthrop P., University of Kansas, Lawrence, Kans.

Heath, Eugene Schofield, Brookmont, Vinings, Ga.

Henderson, Junius, University of Colorado, Boulder, Colo.

Holland, William J., Carnegie Museum, Pittsburgh, Pa.

Holdick, ARThUR, 61 Wall street, New Brighton, N. Y.

Howell, B. F., Department of Geology, Princeton University, Princeton, N. J.

Hudson, George H., 19 Broad Street, Plattsburg, N. Y.

Hussakof, Louis, American Museum of Natural History, New York City.

HydE, Jesse, Western Reserve University, CJeveland, Ohio.

JACKSON, RoBert T., Peterborough, N. Y.

JeFFREY, E. C., Harvard University, Cambridge, Mass.

Jennings, Otтo E., Carnegie Museum, Pittsburgh, Pa.

Kellogg, Remington, 3102 24th Street N. E., Washington, D. C.

KEw, W. S. W., U. S. Geological Survey, Washington, D. C.

Kindle, Edward M., Geological Survey of Canada, Ottawa, Canada.

KIRK, EDwin, U. S. Geological Survey, Washington, D. C.

KNIGHT, S. H., University of Wyoming, Laramie, Wyo.

Knowlton, Frank H., U. S. Geological Survey, Washington, D. C.

LeE, Widus T., U. S. Geological Survey, Washington, D. C.

Loet, Wayne Frederick, General Petroleum Corporation, Higgins Building,

Los Angeles, Calif.

Loomis, Frederick B., Amherst College, Amherst, Mass.

Luld, Richard S.; Yale University, New Haven, Conn.

LUTHER, D. D., Naples, N. Y.

McBrine, Thomas H., University of Iowa, Iowa City, Iowa.

McGregor, J. H., Columbia University, New York City.

Mansfieid, Wendell C., U. S. Geological Survey, Washington, D. C.

Mark, Clara G., Department of Geol., Ohio State University, Columbus, ohio.

Martin, Bruce, Waukena, Thilare County, Calif.

Mather, K. F., Queens University, Kingston, Ontario.

- Matriew, W. D. American Museum of Natural History, New York City.

Maynard, T. Poore, 1622 D. Hunt Building, Atlanta, Ga.

McEwan, Eula D., 5610 Dorchester Arenue, Chicago, Ill. 
Mehl, Maurice G., University of Missouri, Columbia, Mo.

Merriam, JoHn C., University of California, Berkeley, Calif.

Mesler, Rector D., U. S. Geological Survey, Washington, D. C.

MoopIe, RoY L., University of Illinois, Congress and Honore Sts., Chicago, III.

Moody, Clarence L., University of California, Berkeley, Calif.

Moody, W. O., 1829 Berryman Street, Berkeley, Calif.

Mook, Charles C., American Museum of Natural History, New York City.

Mooke, R. C., Department of Geology, University of Kansas, Lawrence, Kaus

Moran, Robert B., 408 S. Spring Street, Los Angeles, Calif.

Monse, William C., Department of Geology, Mississippi Agricultural and Me chanical College, Agricultural College, Miss.

Narraway, JAMES E., Department of Justice, Ottawa, Canada.

Nomland, Jorgen O., 200 Bush Street, San Francisco, Calif.

O'Connel, Marjorie, Columbia University, New York City.

Oldroyd, Ida Carter, Dept. of Geology, Stanford University, Palo Alto, Calif.

Osborn, Henry Fairfield, American Museum of Natural History, N. Y. City.

Pack, R. W., U. S. Geological Survey, Washington, D. C.

Packard, EARL L., Mississippi Agricultural and Mechanical College, Agricultural College, Miss.

Parks, William A., University of Toronto, Toronto, Canada.

Patten, William, Dartmouth College, Hanover, N. H.

Peterson, O. A., Carnegie Museum, Pittsburgh, Pa.

Petrunkevitch, Alexander, 266 Livingston Street, New Haven, Conn.

Prtce, Wrldtam A., Jr., West Virginia University, Morgantown, W. Va.

Raymond, Percy E., Museum of Comparative Zoology, Cambridge, Mass.

Reeds, Chester A., American Museum of Natural History, New York City.

Reeside, John B., JR., U. S. Geological Survey, Washington, D. C.

Resser, Charles E., U. S. National Museum, Washington, D. C.

RIgGs, E. S., Field Museum of Natural History, Chicago, Ill.

Robinson, Wilbur I., State School of Mines, Golden, Colo.

Roundy, Paul V., U. S. Geological Survey, Washington, D. C.

Rowley, Robert R., Louisiana, Mo.

Ruedemann, Rudouf, Education Building, Albany, N. Y.

Sardeson, Frederick W., 414 Harvard Street, Minneapolis, Minn.

SarLe, Clifton J., University of Arizona, Tucson, Ariz.

Savage, Thomas E., University of Illinois, Urbana, Ill.

Shideler, Wrllam H., Miami, University, Oxford, Ohio.

Schuchert, Charles, Yale University, New Haven, Conn.

Scotr, Wiltiam B., Princeton University, Princeton, N. J.

Sellards, Elias H., University of Texas, Austin, Texas.

ShImer, Hervey W., Massachusetts Institute of Technology, Boston, Mass.

Sinclair, Wilmam J., Princeton University, Princeton, N. J.

Smith, Burnert, Syracuse University, Syracuse, N. Y.

Springer, Frank, U. S. National Museum, Washington, D. C.

Stanton, T. W., U. S. Geological Survey, Washington, D. C.

Stauffer, Clinton R., University of Minnesota, Minneapolis, Minn.

Stephenson, L. W., U. S. Geological Survey, Washington, D. C.

Sternberg, Chartes H., Lawrence, Kans.

Stock, Chester, 492 Seventh Street, San Francisco, Calif.

Stover, Regrnald C., Standard Oil Building, San Francisco, Calif. 
Swartz, Charles K., Johns Hopkins University, Baltimore, Md. Talbot, Mignon, Mt. Holyoke College, South Hadley, Mass.

Teller, Edgar E., 305 Ellicott Street, Buffalo, N. Y.

Thомаs, A: O., Department of Geology, University of Iowa, Iowa Citý, Iowa. Thompson, ALbert, American Museum of Natural History, New York City. Troxell, Edward L., Osborn Botanical Laboratory, New Haven, Conn. 'Twenhorel, Willtam H., University of Wisconsin, Madison, Wis. Twitchell, M. W., Geological Survey of New Jersey, Trenton, N. J. Ulrich, EdWard O., U. S. Geological Survey, Washington, D. C. Unger, Claude E., Pottsville, Pa.

VAN Deloo, JacoB, Education Building, Albany, N. Y.

VAN Ingen, GrLberr, Princeton University, Princeton, N. J.

Van Turd, Francis M., Colorado School of Mines, Golden, Colo.

VAUGHaN, T. WAYLAND, U. S. Geological Survey, Washington, D. C. Vogdes, Anthony W., 2425 First Street, San Diego, Calif.

Wagner, Carroll Marshald, 2520 Wilshire Building, Los Angeles, Calif.

Walcott, Charles D., Smithsonian Institution, Washington, D. C.

Weaver, Charies F., University of Washington, Seattle, Wash.

WeLrer, StUaRT, University of Chicago, Chicago, Ill.

Write, David, U. S. Geological Survey, Washington, D. C.

Whittaker, EDWard J., Geological survey of Canada, Ottawa, Canada.

WIELAND, G. R., Yale University, New Haven, Conn.

Willitams, Merton Y., Geological Survey of Canada, Ottawa, Canada.

Wirson, Altoe F., Victoria Memorial Museum, Ottawa, Canada.

WrLson, Herrick E., Oberlin, Ohio.

Wood, Elvira, Museum of Comparative Zoology, Cambridge, Mass.

Woopring, Wendell P., U. S. Geological Survey, Washington, D. C.

\section{CORRESPONDENT DECEASED}

KoKen, E., died November 24, 1912.

\section{MEMBERS DECEASED}

Calvin, Samuel, died April 17, 1911.

Clark, William B., died July 27, 1917.

BARReLL, JosepH, died May 4, 1919.

Derby, OŔville A., died November 27, 1915.

Eastman, Charles R., died September 27, 1918.

Fontaine, William M., died April 30, 1913.

Gill, Theodore N., died September 25, 1914.

Gordon, Roberi H., died May 10, 1910.

HarPer, George W., died August 19, 1918.

Ha Wver, J. C., died May 15, 1914.

LAMBe, LaWrence M., died March 12, 1919.

LYON, VICTOR W., died August 17, 1919.

Prosser, C. S., died September 11, 1916.

Serly, Henry M., died May 4, 1917.

Wartng, Crarence A., died November 4, 1918.

Wilutams, Henky S., died July 31, 1918.

Williston, Samuex W., died August 30, 1918. 


\section{$M E M B E R S-E L E C T$}

Camp, Charles L., American Museum of Natural History, New York City. Chaney, Ralph W., Old Science Hall, Iowa City, Iowa.

Clark, Thomas H., South Weymouth, Mass.

Coryeld, Horace N., Columbia University, New York City.

Crozed, Georges, 17 Chemin des Celestins, Oullins (Rhone), France.

Decker, Charles E., University of Oklahoma, Norman, Okla.

Hubbard, Beta, Queens College, Kingston, Ontario.

Hume, George S., Milton, Ontario, Canada.

Thorpe, Malcolm R., Peabody Museum, New Haven, Conn.

Van Wrnkle, Katherine E. H., 126 Kelvin Place, Ithaca, N. Y.

Minutes of the Ninth Annual Meeting of the Pacific Coast Section of the Paleontological Society

\section{Chester Stook, Secretary}

The ninth annual meeting of the Pacific Coast Section of the Paleontological Society was held in conjunction with the Cordilleran Section, Geological Society of America, and the Seismological Society of America, at Pasadena, California, June 20, 1919. The societies participated in the third annual meeting of the Pacific Division, American Association for the Adrancement of Science. The meeting of the societies in paleontology, geology, and seismology was called to order by Prof. G. D. Louderback at 9.30 a. m., in Room 205, Throop College of Technology. Prof. B. L. Clark presided while several of the paleontological and geological papers were given.

\section{ILECTION OF OFFICERS}

The following officers were elected for the ensuing year:

President, John C. Merriam, University of California. Vice-President, EarL L. Packard, University of Oregon. Secretary, Chester STock, University of California.

\section{TRIBUTE TO C. A. WARING}

It was moved and carried that the Secretary record in the minutes the regret of the death of Mr. C. A. Waring, a member of the Paleontological Society and lately associated with the State Mining Bureau of California, and to express appreciation of the work and accomplishments of Mr. Waring in the field of invertebrate paleontology of the Pacific roast. 


\section{READING OF PALEONTOLOGICAL PAPERS}

'The following paleontological papers were then read:

STRATIGRAPHIC AND FAUNAL RELATIONS OF THE MEGANOS GROUP (MIDDLE EOCENE), CALIFORNIA

BY B. L. CLARK

CENOZOIC HISTORY OF THE GROUND SLOTH GROUP

BY CHESTER STOCK

(Abstract)

The gravigrade edentates afford an interesting example of mammalian evolution during the Cenozoic in America. They are intimately associated with the Tertiary and Pleistocene histories of North and South America and indicate former land connections between the two continents, with evidence as to periods of such connections. Genera of the ground sloth group, known from the Miocene, Pliocene, and Pleistocene, arrange themselves in phylogenetic series illustrating principles of paleontology.

Mr. J. Z. Gilbert spoke concerning some recent investigations of the fossil fishes of California.

Following the presentation of the program the meeting adjourned.

LUNCHEON AND EXOURSIONS

Members of the Paleontological Society partook of luncheon served, through the courtesy of the Throop College of Technology, to the Pacific Division, American Association for the Adrancement of Science, on Thursday and Friday, June 19 and 20, 1919. Members of the. Society also attended a dinner of the Western Society of Naturalists on Friday evening, June 20, 1919, at the Maryland Hotel, Pasadena.

Under the direction of Dr. Frank S. Daggett, Director of the Museum of History, Science, and Art, in Los Angeles, California, an excursion was made to the Pleistocene asphalt deposits of Rancho La Brea. Later the visiting members returned to the museum and viewed the collections of vertebrate remains secured from the asphalt beds. 